\title{
APPLICATION OF ENZYMATICALLY HYDROLYZED-LACTOSE MILK AND WHEY IN SOME DAIRY PRODUCTS
}

\author{
Waleed A. Mahmood \\ Food Sci. Dept./ College of Agric. and \\ Forestry, Mosul Univ., Iraq \\ E-mail: waleedahmed53@yahoo.com \\ Karzan T. Mahmood \\ Food Sci. Dept./ College of Agric., \\ Sulaimania Univ., Iraq
}

\section{ABSTRACT}

Kluyveromyces lactis $\beta$-Galactosidase was used to hydrolyze lactose in milk (28 and 56\% hydrolysis) and in whey (26.25 and 52.5\% hydrolysis). Hydrolyzed-lactose milk was used for the production of ice cream and stirred flavored yogurt while the hydrolyzed-lactose whey was used for the production of a soft drink (whey beverage). The added sucrose to these products was decreased to compensate the sweetness that gained as a result of lactose hydrolysis. The percentages of saved sucrose in ice cream were 6.53 and $13.06 \%$ for 28 and $56 \%$ hydrolyzed-lactose samples, respectively. Sensory evaluation of ice cream sweetness showed non-significant difference $(p \leq 0.05)$ between the hydrolyzed-lactose samples (28 and 56\% hydrolysis) and the untreated sample except for texture where a significant difference was observed between the $56 \%$ hydrolyzed-lactose ice cream and the control sample.

The percentages of sucrose saving in stirred flavored yogurt were equal to 7.42 and $14.84 \%$ for 25.83 and $51.66 \%$ lactose hydrolysis, respectively, whereas in whey beverage they were equal to 3.25 and $6.5 \%$ for 26.25 and $52.5 \%$ lactose hydrolysis, respectively. Sweetness sensory evaluation of the stirred flavored yogurt and whey beverage showed non-significant differences among hydrolyzed-lactose samples and the untreated samples.

Keywords: $\beta$-galactosidase, Lactose hydrolysis, Ice cream, Yogurt, Whey. Corresponding author: Waleed A. Mahmood, Email: waleedahmed53@yahoo.com

Received: 21/10/2012, Accepted: 17/12/2012.

\section{INTRODUCTION}

Lactose is the main carbohydrate component of milk (3-8\% w/v) and cheese whey (70-80\% of the solid component) (Speer, 1998 and Domingues et al., 2000). Every year, millions of tons of whey are produced worldwide. Unfortunately, half of the world production has been wasted directly into aqueous habitat which causes a huge waste disposal problem. This situation creates major environmental pollution due to the high biological oxygen demand (BOD) of lactose stream (Moeini et al., 2004 and Haider and Husain, 2007). Enzymatic hydrolysis of whey lactose by $\beta$ galactosidase (EC 3.2.1.23) into glucose and galactose can reduce more than $75 \%$ of water pollution by converting whey into very useful sweet syrup and generating important food and pharmaceutical products applications (e.g. substitute for corn syrup in soft drinks, fermented beverages, baking, animal feed) (Pivarnik et al., 1995 and Jurado et al., 2002). Lactose use in nutritious products is limited because of low solubility, low sweetening power and causing nutritional malabsorption known as The paper is a part of PhD Dissertation of the second author. 
lactose intolerance (Ferreira et al., 2003). Moreover, the high lactose content in milk products such as ice-cream, frozen milk, whey spreads and condensed milk, can lead to excessive lactose crystallization resulting in products with sandy or gritty texture. Using $\beta$-galactosidase to process such products can reduce lactose concentrations to acceptable values, and so improve some technological and sensorial quality of dairy foods; e.g. increasing the digestibility, softness, creaminess, etc. (Zadow, 1993).

Another advantage of the enzymatic lactose hydrolysis is the simultaneous formation of galactooligosaccharides (GOS), used as prebiotic food ingredients. These compounds are indigestible and acting as dietary fibers. They promote growth of intestinal bifidobacteria, with subsequent healthy effects in the intestine and liver. Nowadays, the demand for GOS production, as well as the development of an effective and inexpensive GOS manufacture has been significantly increased (Grosova et al., 2003).

Commercial yogurt frequently contain appreciable amounts of lactose due to the practice of fortifying the yogurt mix with non fat milk solids. Flavored yogurt can be sweetened by hydrolyzing its lactose, resulting in greater sweetness without increasing its caloric content. (Streiff et al., 1990).

The aim of the present study was the production of hydrolyzed lactose milk and whey by treating with Kluyveromyces lactis $\beta$-galactosidase and manufacturing some hydrolyzed lactose dairy products including ice cream, stirred flavored yogurt and whey-based beverage.

\section{MATERIALS AND METHODS}

Microorganisms and cultural conditions: The yeast Kluyveromyces lactis DSM 70800 was obtained from the Microbiological Resources Center (MIRCEN), Cairo, Egypt and used as the producer of $\beta$-galactosidase. The culture was maintained on potato dextrose agar slants and used to inoculate $500 \mathrm{~mL}$ Erlenmeyer flasks containing $100 \mathrm{ml}$ of the enzyme production medium (yeast extract lactose peptone medium, YLP) which contained: $10 \mathrm{~g} \mathrm{l}^{-1}$ yeast extract, $40 \mathrm{~g} \mathrm{l}^{-1}$ lactose and $5 \mathrm{~g} \mathrm{l}^{-1}$ peptone, $\mathrm{pH}$ 5.5. The flasks were incubated in a shaker incubator at $30^{\circ} \mathrm{C}, 100 \mathrm{rpm}$. for two days. (Becerra et al., 1998).

A lyophilized mixed culture containing Streptococcus thermophilus and Lactobacillus delbrueckii subsp. bulgaricus (Danisco, France) was used as a starter culture for yogurt manufacturing. The culture was maintained on skimmed milk medium.

Fresh cow's milk was obtained from the dairy technology unit (Dairy Science Dept. Faculty of Agric., Cairo Univ.). Cheese whey was obtained from the Training Center Project for Dairy Technology, Dairy Science Dept. Faculty of Agriculture, Cairo University. All chemicals used were of analytical grade.

$\boldsymbol{\beta}$-Galactosidase isolation and precipitation: At the end of incubation period, Kluyveromyces lactis cells were harvested by centrifugation at $4000 \mathrm{rpm}$ for $10 \mathrm{~min}$. The yeast biomass was washed twice with distilled water and suspended in phosphate buffer ( $0.2 \mathrm{M}, \mathrm{pH} 7.0)$. To release the intracellular enzyme, the yeast cells suspension was treated by ultrasonic water bath (CREST ultrasonic) at $10^{\circ} \mathrm{C}$ for 30 minutes. The 
cellular debris was removed by centrifugation at $8000 \mathrm{~g}$ for 15 minutes. $\beta$ galactosidase was precipitated from the cell-free extract using one volume of cold acetone. The precipitate was dissolved in Tris-acetate buffer $(0.1 \mathrm{M}, \mathrm{pH} 7)$ and used as a crude enzyme.

及-Galactosidase assay: The method described by Fekete et al. (2007) was used with some modifications. A reaction mixture consisting of $200 \mu \mathrm{l}$ enzyme sample, $1.0 \mathrm{ml}$ of phosphate buffer $(0.2 \mathrm{M}, \mathrm{pH} 7.0), 1.0 \mathrm{ml}$ of o-nitrophenyl- $\beta$-D-galactopyranoside (ONPG) was incubated at $40{ }^{\circ} \mathrm{C}$, for 10 minutes. The reaction was terminated by adding $0.4 \mathrm{ml}$ of $1 \mathrm{M} \mathrm{Na}_{2} \mathrm{CO}_{3}$ and the liberated o-nitrophenol (ONP) was measured by recording the absorbance at $420 \mathrm{~nm}$ using a standard curve of ONP. Enzyme unit corresponds to the amount of the enzyme which liberates one $\mu$ mole of o-nitrophenol from ONPG per minute under the experiment conditions.

Glucose determination: Glucose was determined according to Trinder (1969) using the enzymatic colorimetric method. Ten $\mu$ of the sample or standard solution $(100 \mathrm{mg}$ $\mathrm{dl}^{-1}$ glucose) was added to $1000 \mu \mathrm{l}$ of a reagent solution consisting of glucose oxidase (5000 unit $1^{-1}$ ) and peroxidase (500 unit $1^{-1}$ ) with phenol as the chromogen. After incubation at $37^{\circ} \mathrm{C}$ for $10 \mathrm{~min}$, the change in absorbance at $510 \mathrm{~nm}$ was recorded. Glucose concentration was calculated according to the following equation:

Glucose conc. $\left(\mathrm{mg} \mathrm{dl}^{-1}\right)=\frac{\Delta_{510}(\text { Sample })}{\Delta_{510}(\text { Standard })} \times \quad$ Standard conc.

Lactose determination: Lactose in milk and whey was determined following the method of phenol-sulphuric acid carbohydrate assay (Dubois et al., 1979).

Hydrolysis of milk and whey lactose: Batch hydrolysis process was used in which one liter of milk or whey was pasteurized for 15 seconds at $72^{\circ} \mathrm{C}$, cooled to $30^{\circ} \mathrm{C}$ and then treated with 31.5 units of $\beta$-galactosidase for 2.5 hour. Aliquots of $0.25 \mathrm{ml}$ were withdrawn at 30 minutes intervals to estimate the concentration of produced glucose.

Lactose hydrolysis calculation: In order to calculate the percentage of lactose hydrolysis in milk and whey, lactose percentage was determined in milk and whey prior to enzymatic treatment. After lactose hydrolysis, the concentration of produced glucose was estimated as described previously.

As known, when one mole of lactose (342gm) is hydrolyzed, it produces one mole $(180 \mathrm{gm})$ of each of glucose and galactose. The amount of hydrolyzed lactose can be calculated as follows:

Amount of hydrolyzed lactose $(\mathrm{gm})=$ amount of produced glucose $(\mathrm{gm}) \times 342 / 180$

$$
\text { Hydrolyzed lactose }(\%)=\frac{\text { amount of hydrolyzed lactose }}{\text { amount of initial lactose }} \times 100
$$

Ice cream manufacturing: The ice cream mix, prepared from cow's milk, contained $8 \%$ fat, $13 \%$ solids non-fat (SNF), $14 \%$ sucrose and $0.5 \%$ gelatin. Lactose percentage was estimated to be $8.1 \%$. The mix was pasteurized at $72^{\circ} \mathrm{C}$ for 10 minutes, cooled 
and aged at $5^{\circ} \mathrm{C}$ for 24 hours followed by primary freezing. The produced ice cream was distributed in $200 \mathrm{ml}$ plastic containers, hardened at $-15^{\circ} \mathrm{C}$ for 6 hours and subjected to sensory evaluation tests (sweetness and texture) and overrun determination. Concerning the production of hydrolyzed-lactose ice cream, the mix components, except sucrose and gelatin, were mixed together, pasteurized and cooled to $30^{\circ} \mathrm{C}$. Sixty three units of $\beta$-galactosidase were added to one liter of mixture followed by incubation at this temperature for 2.5 hours. Sucrose and gelatin were then added and the manufacturing process was continued as above.

Yogurt manufacturing: Cow's milk, containing 3.5\% fat, was used for yogurt production. Lactose percentage was estimated to be $5.7 \%$. Milk was pasteurized at $72^{\circ} \mathrm{C}$ for 15 seconds. Yogurt was manufactured using three milk samples: 1unhydrolyzed-lactose milk (control), 2- milk with $25.83 \%$ hydrolyzed lactose, 3 - milk with $51.66 \%$ hydrolyzed lactose. All samples were then inoculated with $4 \%$ of the starter and incubated at $43 \pm 2^{\circ} \mathrm{C}$ for 3.5 hour.

To produce stirred flavored yogurts, yogurt gel was stirred in a blender for 1-2 minutes followed by adding $8 \%$ of sucrose to the control sample (Pohjanheimo and Sandell, 2009). The quantities of sugar which were added to the second and third samples were reduced according to the percentage of lactose hydrolysis degree to reach the same sweetness of the control sample. To all treatments, $15 \%(\mathrm{w} / \mathrm{v})$ of blended strawberry fruits were added. Samples were stored at $4-5^{\circ} \mathrm{C}$ and subjected to sweetness sensory evaluation.

Whey beverage manufacturing: Whey beverages were produced from unhydrolyzedlactose cheese whey (containing 4.3\% lactose), 26.25 and 52.5\% hydrolyzedlactose whey. The control (untreated) sample was sweetened by adding $14 \%$ sucrose. The quantities of added sucrose to the lactose hydrolyzed whey were reduced depending on the percentage of lactose hydrolysis to compensate the sweetness which gained from lactose hydrolysis. To all samples, $0.05 \%$ of strawberry flavor (Kamena Products Corporation, Cairo-Egypt) was added in order to cover up the undesirable whey flavor and improve the taste. All samples were cooled to $4-5^{\circ} \mathrm{C}$ and subjected to sensory evaluation for sweetness.

Sucrose saving calculations: The sweetness of sucrose and lactose are known to be 100 and 16, respectively. The products of lactose hydrolysis are glucose and galactose. Their relative sweetnesses are 75 and 32, respectively.

The following steps were used for calculating sucrose saving:

a- The sweetness produced from glucose $=$ amount of glucose $\times 75$.

b- The sweetness produced from galactose $=$ amount of galactose $\times 32$.

c- The sweetness loss due to lactose disappear $=$ amount of hydrolyzed lactose $\times 16$.

d- The total gain of sweetness $=(a+b)-c$.

As known, the relative sweetness of sucrose is $100 \%$.

Thus, the amount of saved sucrose $=(a+b)-c / 100$.

The percentage of saved sucrose in each product can be calculated using the following equation: 
Mesopotamia J. of Agric.

Vol. (45) No. (1) 2017
ISSN: 2224 - 9796 (Online)

ISSN: 1815 - 316 X (Print)

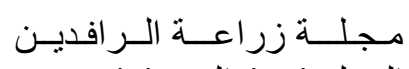

المجلد (45) العدد (1) 2017

$$
\text { Saved sucrose }(\%)=\frac{\text { amount of saved sucrose }}{\text { amount of original added sucrose }} \times 100
$$

Determination of ice cream overrun: Overrun measurement was determined according to the method mentioned by Muse and Hartel (2004) by comparing the weight of ice cream mix and produced ice cream of a fixed volume container using the following equation.

$$
\text { Overrun }(\%)=\frac{\text { Weight of } 200 \mathrm{ml} \mathrm{mix}-\text { weight of } 200 \mathrm{ml} \text { ice cream }}{\text { Weight of } 200 \mathrm{ml} \text { ice cream }} \times 100
$$

Sensory evaluation: Ranking test (Meilgaard et al., 1991) was used to determine the sensory evaluation for sweetness. The evaluation was conducted by the staff members of Dairy Science Dept. Faculty of Agriculture, Cairo University. Stirred flavored yogurt and whey beverage samples were assigned randomly by selecting four digit codes. Panelists ranked the samples in the order of increasing sweetness $\quad(1=$ least sweet and $4=$ most sweet). The texture of ice cream was evaluated by testing the sample resistance against the dipping force. Samples were ranked in the order of their ease of dip ability ( $1=$ easiest to dip and $4=$ hardest to dip).

Statistical analysis: The data were statistically analyzed according to the Methods of Analysis of Variance as a general test. Factorial CRD experiment with three replications was used for $\mathrm{pH}$ development of yogurt. For the sweetness and texture sensory evaluation, the Kruskal-Wallis one-way analysis of variance by ranks was used to analyze results. All possible comparisons among the means were carried out by using Least Significant Difference (LSD) test at a significant level of $p \leq 0.05$.

\section{RESULTS AND DISCUSSION}

Lactose hydrolysis: Table (1) illustrates hydrolysis rates of lactose in milk and whey by Kluyveromyces lactis $\beta$-galactosidase using batch process. It was found that 51.66 and $52.5 \%$ of lactose was hydrolyzed in milk and whey within 2.5 hours, respectively.

Table (1): Hydrolysis of milk and whey lactoses by Kluyveromyces lactis $\beta$-galactosidase using batch process.

\begin{tabular}{|c|c|c|}
\hline \multirow{2}{*}{$\begin{array}{c}\text { Incubation time } \\
\text { (hour) }\end{array}$} & Milk & Wydrolysis degree (\%)* \\
\cline { 2 - 3 } & $0.00 \pm 0.00$ & $0.00 \pm 0.00$ \\
\hline 0 & $8.71 \pm 0.01$ & $12.96 \pm 0.04$ \\
\hline 0.5 & $17.29 \pm 0.01$ & $28.54 \pm 0.04$ \\
\hline 1 & $30.69 \pm 0.06$ & $41.68 \pm 0.01$ \\
\hline 1.5 & $41.52 \pm 0.01$ & $48.54 \pm 0.01$ \\
\hline 2 & $51.66 \pm 0.04$ & $52.50 \pm 0.01$ \\
\hline 2.5 & & \\
\hline
\end{tabular}

* values represent the mean of three replications. 
Hydrolysis rate in this study was slightly lower than that reported for Aspergillus oryzae $\beta$-galactosidase in which 61 and $70 \%$ of lactose were hydrolyzed in milk and whey within 3 hours, respectively (Haider and Husain, 2009). Lactose hydrolysis rate depends on $\beta$-galactosidase activity, which is affected by the reaction conditions such as enzyme concentration, $\mathrm{pH}$, temperature and hydrolysis time (Panesar et al., 2007).

Ice cream sensory evaluation: Sensory evaluation of unhydrolyzed and hydrolyzedlactose samples showed non-significant differences in sweetness among all treatments in spite of the different amounts of added sweetener. This result confirms the effect of lactose hydrolysis products on compensating the decrease in added sucrose. Similar observation was recorded by Zadow (1986) and Matak (1999a) who noticed increased sweetness in ice cream due to lactose hydrolysis. On the contrary, no difference in sweetness of custard samples was detected upon treating with $\beta$-galactosidase (Sutton et al., 1995). The variations in the obtained results could be attributed to the individual acceptance and palatability of the panelists and the experiment conditions.

A significant decrease $(\mathrm{p} \leq 0.05)$ in ice cream texture (dip ability) was observed in the $56 \%$ lactose-hydrolyzed as compared to the control sample (unhydrolyzed) while the decrease in $28 \%$ hydrolyzed-lactose sample texture was non-significant (Table 2). Matak (1999 b) recorded significant differences in dip ability between the control and both 80 and $100 \%$ hydrolyzed-lactose samples.

The hardness of ice cream is important for improving dipping property which is affected by ice crystals sizes (Muse and Hartel, 2004). Sakurai et al. (1996) found that ice creams with larger ice crystals appeared harder than those with small ice crystals. Due to high solubility of glucose and galactose as compared to lactose, hydrolysis of lactose decreases the free water, lowers the sizes of ice crystals and allows incorporation of more milk solids resulting in the production of frozen milk products having improved quality. High lactose content of ice cream mix leads to develop sandy texture as a result of lactose crystallization in the final product (Marshall, 1991). Due to lactose hydrolysis, the amount of lactose is reduced resulting in a product with lower prone to crystallization (Matak, 1999 a).

Table (2): Effect of lactose hydrolysis on sweetness, texture, overrun and saved sucrose of ice cream.

\begin{tabular}{|c|c|c|c|c|c|}
\hline \multirow{2}{*}{$\begin{array}{c}\text { Lactose } \\
\text { hydrolysis }(\%)\end{array}$} & Sweetness & \multirow{2}{*}{$\begin{array}{c}\text { Body and } \\
\text { texture }\end{array}$} & $\begin{array}{c}\text { Overrun } \\
(\%)\end{array}$ & \multicolumn{2}{|c|}{ Saved sucrose } \\
\cline { 5 - 6 } & & & $\mathrm{g} \mathrm{l}^{-1}$ & $\%$ of added sugar \\
\hline 0.0 (control) & $3.34 \mathrm{a}$ & $3.70 \mathrm{a}$ & $39.15 \mathrm{a}$ & 0.00 & 0.00 \\
\hline 28 & $3.13 \mathrm{a}$ & $3.56 \mathrm{a}$ & $39.08 \mathrm{a}$ & 9.14 & 6.53 \\
\hline 56 & $3.06 \mathrm{a}$ & $2.97 \mathrm{~b}$ & $41.37 \mathrm{a}$ & 18.28 & 13.06 \\
\hline
\end{tabular}

Values designated with different letters within columns are significantly different $(p<0.05)$.

Ice-Cream Overrun: Table (2) shows that the overrun percentages were 39.15, 39.08 and $41.37 \%$ for 0,28 and $56 \%$ lactose hydrolysis, respectively, with non-significant differences among them. Similar result was observed by Matak (1999 b) who reported 
that overrun was maintained at $76 \pm 1.66 \%$ for all replications of lactose hydrolysis levels.

Different values for ice cream overrun were obtained by differnt workers. The differences may be due to the variations in mixes composition. Salem et al. (2003) found that the replacement of milk fat in ice cream mix with Jerusalem artichoke inulin had led to slight decrease in overrun while Cruz et al. (2009) detected higher overrun values and less change in melting properties in ice-cream mixes containing inulin.

Sucrose saving in ice cream manufacturing: Lactose hydrolysis in ice cream mix into glucose and galactose, which are relatively sweeter than lactose, caused an increase in the product sweetness. In order to produce ice cream with the same sweetness, the amount of added sugar (sucrose) was reduced to compensate the sweetness that gained as a result of lactose hydrolysis and was calculated to be 130.86 and $121.72 \mathrm{~g} \mathrm{l}^{-1}$ for 28 and $56 \%$ lactose hydrolysis samples, respectively compared to $140 \mathrm{~g} \mathrm{l}^{-1}$ for unhydrolyzed-lactose mixture. The percentages of the saved sucrose were calculated to be 6.53 and $13.06 \%$ for the above mentioned hydrolysis degrees, respectively (Table 2 ).

Initial lactose content of ice cream mix was estimated to be $8.1 \%$. After incubation with the enzyme, lactose hydrolysis reached $56 \%$ and $23.87 \mathrm{~g} \mathrm{l}^{-1}$ of each of glucose and galactose were produced. The amount of hydrolyzed lactose was $45.35 \mathrm{~g} \mathrm{l}^{-}$ 1 . The amount of saved sucrose was calculated to be $18.28 \mathrm{~g}$ per one liter of the mix which corresponds to $13.06 \%$ of added sucrose. Concerning the $28 \%$ hydrolyzedlactose mix, the amounts of produced glucose and galactose were $11.94 \mathrm{~g} \mathrm{l}^{-1}$ each and the amount of saved sucrose was calculated to be $9.14 \mathrm{~g}$ per liter of mix which corresponds to $6.53 \%$ of added sucrose.

Sensory evaluation of yogurt: Sensory evaluation results of stirred flavored yogurt showed that the untreated yogurt had non-significant higher scores of sweetness than 25.83 and $51.66 \%$ hydrolyzed-lactose yogurts (Table 3). The overall acceptance of yogurt is strongly related to sweetness (Harper et al., 1991). Barnes et al. (1991) advised dairy manufacturers to produce very sweet yogurt rather than too sour flavored yogurt in order to ensure a high overall acceptance. However, added sugar may lessen its health benefits (Pohjanheimo and Sandell, 2009). This aspect magnifies the desirable attribute of reducing calories in a sweetened yogurt.

Sucrose saving in yogurt manufacturing: The initial percentage of lactose in milk which was used for stirred flavored yogurt production was 5.7\%. After incubation with $\beta$-galactosidase, 25.83 and $51.66 \%$ of lactose hydrolysis were obtained. Since the amount of added sucrose to untreated yogurt sample was equal to $80 \mathrm{~g} \mathrm{l}^{-1}$, so the amounts of saved sucrose were calculated to be 5.94 and $11.87 \mathrm{~g} \mathrm{l}^{-1}$ which correspond to 7.42 and $14.84 \%$ of added sucrose for the above mentioned hydrolysis degrees, respectively (Table 3 ). Increased health benefits and less caloric values of flavored yogurt could be obtained through lactose hydrolysis by minimizing the amount of added sucrose without affecting the overall sweetness. 
Table (3): Effect of lactose hydrolysis on sweetness and saved sucrose of stirred flavored yogurt.

\begin{tabular}{|c|c|c|c|}
\hline \multirow{2}{*}{ Lactose hydrolysis (\%) } & \multirow{2}{*}{ Sweetness } & \multicolumn{2}{|c|}{ Saved sucrose } \\
\cline { 3 - 4 } & & $\mathrm{g} \mathrm{l}^{-1}$ & \% of added sucrose \\
\hline 00.00 & $3.00 \mathrm{a}$ & 0.00 & 0.00 \\
\hline 25.83 & $2.83 \mathrm{a}$ & 5.94 & 7.42 \\
\hline 51.66 & $2.82 \mathrm{a}$ & 11.87 & 14.84 \\
\hline
\end{tabular}

Values designated with different letters within columns are significantly different $(\mathrm{p}<0.05)$.

To estimate the effect of lactose hydrolysis on the rate of milk $\mathrm{pH}$ decreasing during yogurt manufacturing, the $\mathrm{pH}$ values of yogurt samples were measured every 30 minutes of incubation. The data showed that there were a significant decrease in $\mathrm{pH}$ values $(p \leq 0.05)$ due to the combined effects of lactose hydrolysis degree and incubation time (Table 4). At the end of the incubation period ( 3 hours), a significant decrease was detected in hydrolyzed-lactose samples. Higher hydrolysis degree caused more decrease in $\mathrm{pH}$ value of the product. This may be due to the availability of more simple sugars (glucose and galactose) to be converted into lactic acid by lactic acid bacteria and lowering the $\mathrm{pH}$ faster than untreated milk.

Table(4): Effect of lactose hydrolysis on milk $\mathrm{pH}$ values during yogurt manufacturing.

\begin{tabular}{|c|c|c|c|}
\hline \multirow{2}{*}{$\begin{array}{c}\text { Incubation time } \\
\text { (hour) }\end{array}$} & \multicolumn{3}{|c|}{$\mathrm{pH}$ values* } \\
\cline { 2 - 4 } & $0 \%$ & $25.83 \%$ & $51.66 \%$ \\
\hline & \multicolumn{3}{|c|}{ Lactose hydrolysis $(\%)$} \\
\hline 0.0 & $6.76 \mathrm{~cd}$ & $6.77 \mathrm{~cd}$ & $6.78 \mathrm{bcd}$ \\
\hline 0.5 & $6.87 \mathrm{a}$ & $6.83 \mathrm{ab}$ & $6.80 \mathrm{bc}$ \\
\hline 1.0 & $6.74 \mathrm{~d}$ & $6.77 \mathrm{~cd}$ & $6.75 \mathrm{~cd}$ \\
\hline 1.5 & $6.52 \mathrm{ef}$ & $6.53 \mathrm{e}$ & $6.47 \mathrm{f}$ \\
\hline 2.0 & $5.90 \mathrm{~g}$ & $5.89 \mathrm{hg}$ & $5.84 \mathrm{~h}$ \\
\hline 2.5 & $5.30 \mathrm{i}$ & $5.28 \mathrm{i}$ & $5.13 \mathrm{j}$ \\
\hline 3.0 & $5.04 \mathrm{k}$ & $4.95 \mathrm{l}$ & $4.83 \mathrm{~m}$ \\
\hline
\end{tabular}

*values designated with different letters are significantly different $(\mathrm{p} \leq 0.05)$.

Sensory evaluation of whey beverage: As shown in Table (5), non-significant differences in sweetness were detected by the panelists in the control and both $\beta$ galactosidase treated samples. Sweetness reduction which was caused by decreasing the added sucrose to hydrolyzed-lactose whey was substituted by the increased sweetness due to the production of lactose hydrolysis products, glucose and galactose. The product taste was found to be acceptable and the undesirable whey flavor was covered up by adding the strawberry flavor. Durić, et al. (2004) suggested the addition of fruits concentrates to the produced cheddar whey-based drink to cover up the undesirable cooked and salty-sour whey flavor. 
Table (5): Effect of lactose hydrolysis on sweetness and saved sucrose of whey-based beverages.

\begin{tabular}{|c|c|c|c|}
\hline \multirow{2}{*}{ Lactose hydrolysis (\%) } & Average rank of & \multicolumn{2}{|c|}{ Saved sucrose } \\
\cline { 3 - 4 } & sweetness $*$ & $\mathrm{~g} \mathrm{l}^{-1}$ & $\%$ of added sucrose \\
\hline 00.00 & $3.36 \mathrm{a}$ & 0.00 & 0.00 \\
\hline 26.25 & $3.01 \mathrm{a}$ & 4.55 & 3.25 \\
\hline 52.50 & $2.99 \mathrm{a}$ & 9.10 & 6.5 \\
\hline
\end{tabular}

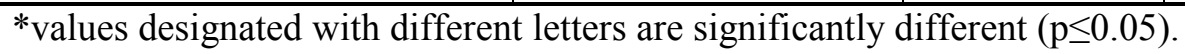

On the other hand, the addition of some artificial sweetening agents (most often saccharin and cyclamate) to whey beverages instead of sucrose to obtain beverages with very low energy possesses a great problem related to some indications of toxicity (Jeličić et al. 2008). Whey beverage with hydrolyzed lactose is rated to develop recipes for dietetic whey beverages by using a lower amount of sugar but without using artificial sweetening agents.

Sucrose saving in whey beverage manufacturing: The amounts of saved sucrose in whey beverage were calculated to be 4.55 and $9.1 \mathrm{gm}$ per one liter of whey which correspond to 3.25 and $6.5 \%$ of added sucrose for 26.25 and $52.5 \%$ lactose hydrolysis, respectively (Table 5).

The use of lactose-hydrolyzed milk and whey in the production of dairy products had remarkably reduced the amounts of added sweeteners. More saving could be achieved by higher degrees of hydrolysis. This has both economical and nutritional benefits. These products have relatively low caloric values and are also somehow suitable to be consumed by people who are suffering from diabetes and lactose intolerance.

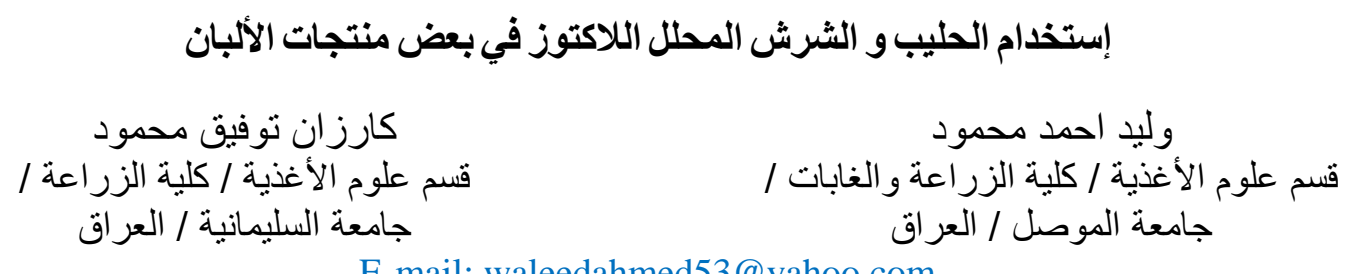

E-mail: waleedahmed53@yahoo.com

\section{الخلاصة}

أستخدم بيتاكالاكتوسيديز خميرة Kluyveromyces lactis في تحلل لاكتوز الحليب و الثرش. أستخدم

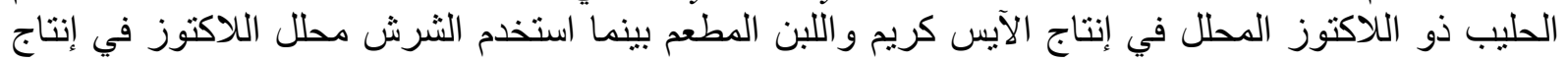

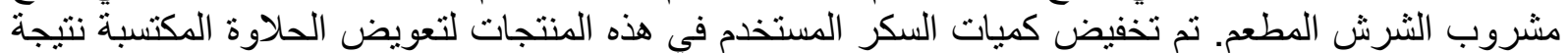

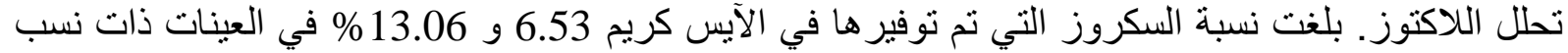

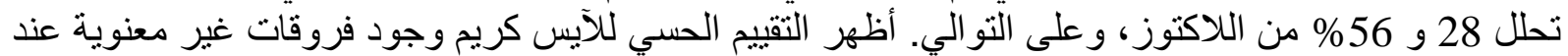

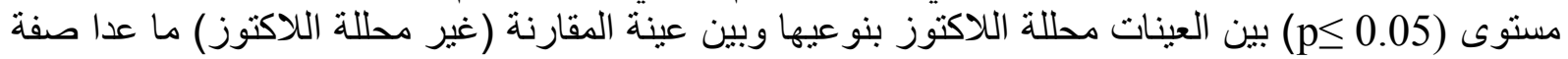

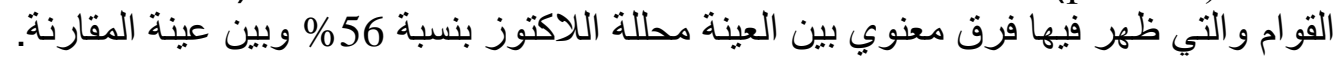

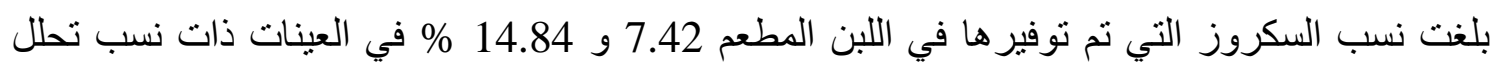

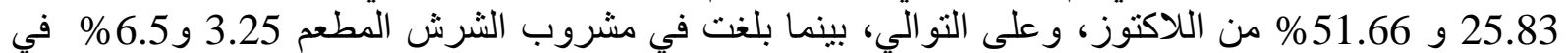


العينات ذات نسب تحلل 26.25 و 52.5\% من اللاكتوز ، وعلى التو الي. بينت نتائج التقييم الحسي للحلاوة في

عينات اللبن المطعم ومشروب الشرش عدم وجود فروقات معنوية بين صفات العينات محللة اللاكتوز و عينات

المقارنة.

الكلمات الدالة: بيتا كالاكتوسيديز، تحلل اللاكتوز ، آيس كريم، لبن، شرش.

تاريخ تسلم البحث: 2012/10/21 ، وقبوله: 2012/12/17.

\section{REFERENCES}

Barnes, D. L.; S. J. Harper; F. W. Bodyfelt and M. R. McDaniel (1991). Correlation of descriptive and consumer panel flavour ratings for commercial prestirred strawberry and lemon yoghurts. Journal of Dairy Science 74: 2089-2099.

Becerra, M.; E. Cerdản and M.I. Gonzảlez Siso (1998). Dealing with different methods for Kluyveromyces lactis $\beta$-galactosidase purification. Biological Procedure Online 1 (1): 48-58.

Cruz, A. G.; A. E. C. Antunes; O. P. Ana Lucia Sousa; J. A. F. Faria and S. M. Saad (2009). Ice-cream as a probiotic food carrier- Review. Food Research International 42(9): 1233-1239.

Domingues L.; M. L. Onnela; J.A. Teixeira; N. Lima and M. Penttila (2000). Construction of a flocculent brewers yeast strain secreting Aspergillus niger $\beta$ galactosidase. Applied Microbial Biotechnology 51(1): 97-103.

Dubois, M.; K.A. Gilles; J.K. Hamilton; P.A. Rebers and F. Smith (1979). Colorimetric method for the determination of sugars and related substances. Analytical Chemistry 28:350-356.

Durić, M.; M. Carić; S. Milanović; M. Terić and M. Panić (2004). Development of whey based beverages. European Food Research and Technology 219: 321 328.

Fekete, E.; L. Karaffa; C. P. Kubicek; A. Szentirmai and B. Seiboth (2007). Induction of extracellular $\beta$-galactosidase (Bga1) formation by D-galactose in Hypocrea jecorina is mediated by galactitol. Microbiology 153 (20): 507-512.

Ferreira, L. S.; M. B. Souza Jr; J. O. Trierweiler; B. Hitzmann and R. O. M. Folly (2003). Analysis of experimental biosensor/ FIA lactose measurements. Brazilian Journal of Chemical Engineering 20 (1): 7-9.

Grosova Z.; M. Rosenberg and M. Rebroš (2008). Perspectives and applications of immobilised $\beta$-galactosidase in food industry - a review. Czech Journal of Food Science 26: 1-14.

Haider, T. and Q. Husain (2007). Calcium alginate entrapped preparations of Aspergillus oryzae $\beta$-galactosidase: Its stability and applications in the hydrolysis of lactose. International Journal of Biological Macromolecules 41: 72-80.

Haider, T. and Q. Husain (2009). Hydrolysis of milk/whey lactose by $\beta$-galactosidase: A comparative study of stirred batch process and packed bed reactor prepared with calcium alginate entrapped enzyme. Chemical Engineering Processing 48: 576-580. 
Harper, S. J.; D. L. Barnes; F. W. Bodyfelt and M. R. McDaniel (1991). Sensory ratings of commercial plain yoghurts by consumer and descriptive panels. Journal of Dairy Science 74: 2927-2935.

Jeličić, I., R. Božanić and L. Tratnik (2008). Whey-based beverages -a new generation of diary products. Mljekarstvo 58(3): 257-274.

Jurado E.; F. Camacho; G. Luzon and J.M. Vicaria (2002). A new kinetic model proposed for enzymatic hydrolysis of lactose by $\beta$-galactosidase from Kluyveromyces fragilis. Enzyme and Microbiol Technology 31: 300-309.

Marshall, R. (1991). A 'cure' for lactose intolerance. Dairy Field 40-41.

Matak, K. M. (1999a) . Lactose hydrolysis by yeast lactase: influence on freezing point and dipping characteristics of ice cream. Chapter III, MSc. Thesis. Lactose hydrolysis by fungal and yeast lactase: influence on freezing point and dipping characteristics of ice cream. Virginia Tech, Blacksburg, VA. USA.

Matak, K.M. (1999b). physical and sensory measurement of dipping characteristics of lactose-hydrolyzed ice cream. Chapter IV, MSc. Thesis. Lactose hydrolysis by fungal and yeast lactase: influence on freezing point and dipping characteristics ice cream. Virginia Tech, Blacksburg, VA. USA.

Meilgaard, M.; G. Civille and B. T. Carr (1991). Sensory Evaluation Techniques. $2^{\text {nd }}$ ed. CRC Press, Inc., Boca Raton.

Moeini H.; I. Nahvi and M. Tavassoli (2004). Improvement of SCP production and BOD removal of whey with mixed yeast culture. Electronic Journal of Biotechnology 7(3): 252-258.

Muse, M. R. and R. W. Hartel (2004). Ice Cream Structural Elements that Affect Melting Rate and Hardness. Journal of Dairy Science. 87(1): 1-10.

Panesar, R.; P. S. Panesar; R. S. Singh; J. F. Kennedy; M. B. Bera (2007). Production of lactose hydrolyzed milk using ethanol permeabilized yeast cells. Food Chemistry 101: 786-790.

Pivarnik L. F.; Senacal A. G. and Rand A. G. (1995). Hydrolytic and transgalactosylic activities of commercial $\beta$-galactosidase (lactase) in food processing. Advances in Food \& Nutrition Research 38: 1-102.

Pohjanheimo, T. and M. Sandell (2009). Explaining the liking for drinking yoghurt: The role of sensory quality, food choice motives, health concern and product information. International Dairy Journal 19: 459-466.

Sakurai, K.; S. Kokubo; K. Hakamata; M. Tomita and S. Yoshida (1996). Effect of production conditions on ice cream melting resistance and hardness. Milchwissenschaft 51 (8): 451-454.

Salem, A. S.; A. M. Abdel-Salam and S. El-Shibiny (2003). Preparation and properties of low fat and low sugar functional ice cream varieties. Egyptian Journal of Dairy Science 31: 399-409.

Speer, E. (1998). Milk and Dairy Product Technology. Marcel Dekker, New York, U.S.A. 
Streiff, P. J.; D. L. Hoyda and E. Epstein (1990). Process for the production of low calorie yogurt. US Patent: 4956186.

Sutton T. D.; S. E. Duncan; D. Brochetti and A. Ogura (1995). Quality and sweetness of baked custard made with lactose-reduced milks. Journal of Food Quality 18: 379-387.

Trinder, P. (1969). Determination of glucose in blood using glucose oxidase with an alternative oxygen acceptor. Annual Clinical. Biochemistry 6: 24-25.

Zadow, J. G. (1986). Lactose hydrolyzed dairy products. Food Technology Australia 38 (11): 460-471.

Zadow, J. G. (1993). Economic considerations related to the production of lactose and lactose by-products. Bulletin 289, International Dairy Federation. 